\title{
Professionalism of Civil Servants as the Factor of Public Administration Efficiency Growth
}

Yuryeva O.V.a

Butov G.N.b

Malganova I.G.c

Pratchenko O.V. ${ }^{d}$

\author{
a bc Kazan Federal University, Institute of Management, Economics and Finance, Kazan, 420008, Russia \\ Email: irigrimmm@gmail.com \\ a Kazan Federal University, Institute of Language, 420008, Kazan, Russia
}

\section{Doi:10.5901/mjss.2015.v6n1s3p481}

\begin{abstract}
The problems of efficiency growth of state run public authorities and governmental authorities are considered in the article. Professionalism of civil servants is the focus of the authors. Based on an analysis of the current practice of public administration they come to the conclusion that the human resource -knowledge and skills of management activity parties - is in the basis of its performance. The experience of using the competency approach in civil service in the Republic of Tatarstan is summarized in the article.
\end{abstract}

Keywords: efficiency of public service, competency approach, model of competencies, improvement of professionalism of civil servants.

\section{Introduction}

Improvement of efficiency of the civil service is one of the important conditions for overcoming the negative trends in the socio-economic development of the Russian Federation. In our opinion, the main problems in this sphere are the following: replenishment of senior executives by highly qualified competent specialists and radical increase of the professional level of the existing civil servants in performance of their duties.

Complexity of solving these problems is explained, firstly, by the fact that unfortunately the most important values of the democratic society - openness to new experience, commitment to social change, understanding and acceptance of diversity of opinions and attitudes of the other people, the desire to achieve a high level of social and professional standards, the ability to define and defend one's opinion, to be independent and responsible at the same time, to live in conditions of competition in all areas - have not become the prior values for public servants yet.

It is obvious that without assurance in priority of these values, a civil servant can not contribute to formation of the necessary conditions for the development of creativity and initiative of citizens, so the social duty of the state - to create opportunities for every citizen to perform and work freely - can not be enforced.

Secondly, we are convinced that the most important and valuable resource of public administration is a human one; it requires careful handling. However, very often it is necessary to say that be noted that a lot of public servants of all ranks and levels understand this axiom too simply, while the deficit of this resource is definitely the greatest national problem of the present and future of Russia.

At the time, the American researcher of the problems of organizational behavior and management Elton Mayo said that science and art of government are based not only on its socialization, but on psychologization as well, as far as it is important to have the ability to listen, communicate, to show sympathy and to have credibility. The Art of Communication is an essential component of the process of management process. Personal abilities can not substitute this art; no technical skills or the highest production efficiency will compensate its absence [1]. Mayo logically concludes that modern civilization is in great need of servants of the new type who are able to able "to understand social and human facts as they are having thrown away all their emotions and prejudices". But to achieve that, "it must be meticulous training..., including in the organization of cooperation." [1]

Mayo thought that the drawback of contemporary system of management education is that it was not able to teach 
social skills - "the ability to establish communication with others, to inspire by feelings and ideas to others so to promote the innate feeling of participation in a common cause." [1]

A lot of findings of the scientist findings are still relevant today, and if the public service has set a goal to become really professional, it must become competitive in the labor market, to be attractive for highly qualified personnel. Unlike large commercial companies whose financial resources allow not only to select the best candidates from hundreds of applicants, but also to withhold them by weighty social package for the system of civil service, especially for employees of lower echelon and middle ranking, such methods are not applicable yet. However, in the sphere of public service there are other resources which, unfortunately, are involved not enough at present: the prestige of the profession, stability, opportunities for career and professional growth, social concern of the state of its "sovereign people".

Effective solution of the problem of improvement of professionalism of civil servants is restrained by absence of the integrated public authority that would be responsible for selection, choice and assessment of staff for public service.

Due to the fact that establishment of the system of formation and development of personnel reserve in public authorities is at the initial stage, it is almost impossible to give the objective characteristic of this reserve. In its turn, it is the strongest constraining factor for the use of modern methods of the selection of staff that is highly professional, ready to work in the system of public administration for a long time, that has valuable experience of teamwork, that focuses on personal career and service for public interests. But available experience and knowledge of the public and municipal servants do not always match with those that are required for the functioning of public authorities in new conditions.

"I fully agree with those people who think that we have the anachronistic system of public administration and the same system of recruitment," - said D.A. Medvedev at the meeting with the open government in Skolkovo. According to him, "it is obvious that there can not be a modern system of public administration with the old system of staff selection career development, the system of motivation and so on". [2]

It is quite clear that the growth of professionalism of civil servants directly depends on the state of the contingent, on identification of persons who are able to "raise" their professional level. It is necessary to have certain selection criterial in order to make a qualitative selection and evaluation of staff. At this stage the question arises: what are the criteria of evaluation? The experts in the field of personnel assessment have the answer: it is necessary to create the model of competencies which should take into account peculiarities of public servants, describe differences in the requirements for workers of different groups of job positions, which should reflect continuity in development of competencies, which will also contain an integrated description of requirements for knowledge, abilities and skills of public servants required for successful execution of their duties and which should take into account the characteristics of their activities.

\section{Method}

The Republic of Tatarstan can be as a good example of creation of competency models and their application. In 2010 the comprehensive competence approach in the field of civil service in the formation of multi-level personnel prospects was tested and implemented in Tatarstan for the first time among the regions of the Russian Federation by the initiative of the President of the Republic of Tatarstan R.N. Minnikhanov.

Development of the model of competencies of effective public servant of the Republic of Tatarstan was held using modern methods - the focus-group research and the assessment center.

The focus-group research was held with participation of Ministers and Deputy Ministers of the Republic of Tatarstan, the heads of structural subdivisions of the Administration of President and the Cabinet of Ministers of the Republic of Tatarstan. The models obtained were combined into the united integrated model of competencies of managers in the sphere of public authorities and administration of the Republic of Tatarstan. [3]

According to the results of the focus-group research the following basic competencies were determined in order to improve the effectiveness of functions of the Head of the state run public authorities of the republic: strategic and analytical thinking, innovation, performance management, ability of teamwork, communication skills, initiative and managerial responsibility, adequate behavior in stressful situations, leadership.

Heads of public authorities who defined the parameters of success of employees were directly involved in the creation of the model of competencies. The highlighted parameters were put into the basis of the developed competencies of servants. [4]

The established unified model of competencies is currently being applied in the practice of assessment of managerial capacity of public servants by the method of the assessment-center.

Choosing this method, the developers took into account its ability to give comprehensive assessment of staff competencies, based on the use of complementary techniques, its orientation for estimation of real qualities of 
employees, their psychological and professional features, compliance to the requirements of job positions, as well as for identification of potential abilities of managers and specialists.

\section{Results}

The data concerning personal, managerial and professional potential of civil servants obtained with the help of the assessment center became the basis of formation of workforce capacity on different levels of management in the sphere of civil service of the Republic of Tatarstan; it gives reason to the republic's leadership not only to make well-founded personnel decisions, but also to monitor professional development of individuals enrolled into the personnel reserve.

High cost is the factor that restrains to some extent the use of the method of the assessment center for evaluation of all existing public and municipal civil servants of the Republic. However, in the frames of the Program of development of public and municipal service in the Republic of Tatarstan, this method got the support.

For today about 2 million civil servants - deputy ministers, heads of departments and offices, heads of department of ministries and divisions, people from the personnel reserve of public authorities - assessed and passed as managerially competent in the Republic of Tatarstan. Work on assessment of management competencies of municipal servants of the republic also started - by now more than 450 people have already passed this assessment.

According to the assessment the individual plan on the assessed competencies with identification of various activities for development and self-improvement and one of types of additional professional education, to which the civil servant is sent (advanced training, professional retraining or apprenticeship) was formed for every participant.

It should be emphasized that these individual plans are the basis of the above-mentioned Development Program of Public Civil and Municipal Service in the Republic of Tatarstan for 2010-2013 and subsequent years. [5] Higher School of Public and Municipal Administration of the Kazan (Volga Region) Federal University (hereinafter - HSPMA) is a coordinating and methodological body of training the civil and municipal servants.

The results of the program are quite significant: 9225 public and municipal servants were trained during the period of its work.

As far as the spheres of public and municipal administration require specialists of different levels and directions of activities, a wide range of programs is developed and implemented in HSPMA (tab.1).

Table 1. Types of programs for specialists on general management issues in HSPMA

\begin{tabular}{|c|l|c|}
\hline & Programs for specialists on general management issues & The public and municipal servants (persons/ share) \\
\hline 1 & "Fundamentals of Civil and Municipal Service" & $3000 / 32.5 \%$ \\
\hline 2 & $\begin{array}{l}\text { "Legal, analytical and information support of public } \\
\text { administration" }\end{array}$ & $3125 / 33.9 \%$ \\
\hline 3 & $\begin{array}{l}\text { "Middle management in public and municipal administration: } \\
\text { theory and practice" }\end{array}$ & $3100 / 33.6 \%$ \\
\hline
\end{tabular}

Specialization of activities of servants in such spheres as health, education, culture, energy, housing and utilities, is also taken into account: the programs that take into account the specific character of this or that economic sector, also run.

HSPMA pays special attention to the levels (regional or local) and to management functions (strategic management, planning and forecasting, financial management, human resource management): the programs "Innovative methods of development of municipal entities", "National Competition Policy", "Modern technologies of personnel management in the public civil and municipal service", "Financial audit and performance audit in the system of the state financial control" and a number of other programs run here.

Of course, HSPMA does not stand apart from the processes of informational support - modern society is penetrated by information flows and technologies. Increased attention is paid to this very important sphere: the programs "Informational support and communication in the public sector", "Information technologies in public and municipal management", "Communicative management in public administration" are implemented.

\section{Conclusions}

In accordance with the national policy on the questions of anti-corruption, the programs on anti-corruption national policy in the system of public and municipal administration are rather relevant.

It is necessary to say that the content of the developed programs is not of prolonged nature -qualitative and 
quantitative expansion and updating of programs is constantly going. Constant cooperation of HSPMA for development of joint programs with ministries and departments of the republic, the departments of the university, similar structures of other universities of the country plays great role in this. Among these programs there are the following ones: "Management of Special Economic Zones", "Problems of accession of Russia to the WTO," "Work with commercial organizations", "Technologies of development of standards of public and municipal services."

Classes with the use of innovative methods of education in the form of "round tables", workshops, debates, problem-innovative meetings are held in order to achieve maximum efficiency of learning the new material.

Trainings have a special place in the educational process. Practice shows that in most cases the training programs are more effective than traditional forms of education - lectures and seminars. Intensive work during trainings helps to achieve good results in a short time, and the subsequent system of post-training support provides good reinforcement of material. Moreover, repeated polling surveys of students confirm attractiveness and importance of this form.

Human Resourcing of the educational process is an important resource that determines quality of training of civil and municipal servants. To characterize the composition of persons involved by HSPMA for teaching, we will give the following data (tab.2):

Table 2. The composition of persons involved by HSPMA for teaching

\begin{tabular}{|c|l|l|c|}
\hline & The composition of persons & Kind of persons & Share \\
\hline 1 & $\begin{array}{l}\text { Leading specialists of public and } \\
\text { municipal administration }\end{array}$ & Experst, researchers & $46 \%$ \\
\hline 2 & Teaching staff of universities & $\begin{array}{l}\text { Professors, Associat.prof, Senior teachers, } \\
\text { Assistants, Tutors etc. }\end{array}$ & $38 \%$ \\
\hline 3 & $\begin{array}{l}\text { Representatives of public } \\
\text { organizations of the republic }\end{array}$ & $\begin{array}{l}\text { Public Chamber, Committee of Veterans of War and military service, top } \\
\text { managers of enterprises, organizations and institutions }\end{array}$ & $16 \%$ \\
\hline
\end{tabular}

The feedback system - questionnaire survey and opinion polls - are the obligatory elements of assessment of quality of training and satisfaction of it by listeners in HSPMA. For example, a recent opinion poll of more than 900 public servants allowed to make changes to the curricula of students, taking into account their wishes and recommendations.

We think that concentration of efforts and means on training, retraining and advanced training in specialized training centers (schools, academies, institutes) at federal or national universities is one of the urgent problems of efficiency improvement of civil and municipal servants. We are convinced that exactly they are able to solve to these problems. They have the ability to apply an integrated interdisciplinary approach in so important, in the full sense, public affairs.

We believe that training of managers who correspond to modern requirements, own the latest tools and management techniques, who can apply the knowledge in practice, will greatly improve the efficiency of the civil service.

We would like to finish the article by the quote of Bismarck who said that with bad laws and good civil servants it is still possible to rule the state, but with bad civil servants it is impossible to rule the state even with good laws.

\section{References}

Mayo G.E. The Social Problems of an Industrial Civilization.- Division of Research, Harvard Graduate School of Business Administration, Boston, 1945.

Rashirennoe zasedanie rabochey gruppi po formirovaniyu sistemi «Otkritoe pravitelstvo» [Internet resource]: - Access: http://www.kremlin.ru/news/14773.

Focus group on development of model of administrative competences of heads of the ministries and departments, deputy ministers, heads of structural divisions of the ministries and departments of the Republic of Tatarstan [Internet resource]: «Abada». Access: http://www.abadabbr.rulindex.php? cat=news\&new_id=189.

Klenko A.B. Vnedrenie system otcenki competenciy gosudarstvennih sluzhachih [Internet resource]: «Abada». - Access: http://www.abadabbr.ru/index.php?cat=science\&id=adoption_0.

Ukaz Presidenta Republiki Tatarstan R.N. Minnikhanova ot 23 avgusta 2010 г. №YP-552 «Ob utvergdenii Programmi razvitiya gosudarstvennoy grazhdanskoy sluzhbi Respubliki Tatarstan i municipalnoy sluzhbi v Respubliki Tatarstan na 2010-2013 gg.».

Vagizova V.I., Lurie K.M., Ivasiv I.B. Clustering of Russian banks: business models of interaction of the banking sector and the real economy/ V.I. Vagizova, K.M. Lurie, I.B. Ivasiv// Problems and Perspectives in Management. - 2014. - №1., p. 72-82

Ankudinov B., Lebedev O. V. Investment drivers of shareholder value creation in large publicly traded Russian companies // Investment Management and Financial Innovations. - 2014. - 11 (2) . - pp. 77-85.

OECD, (2011). "Government at a glance 2011". Paris: OECD. 
Simpson, H. (2009). Productivity in public services. Journal of Economic Surveys, 23 (2): 250-276.

Van Dooren, W., Lonti, Z., Miekatrien, S. \& Bouckaert, G. (2007). Institutional drivers of efficiency in the Public Sector. Paris: OECD.

OECD, (2010). Modernising the Public Administration: A Study on Italy. Paris: OECD.

Beckett, L. (2011) Professional learning in community: Teachers and academic partners focused on disadvantaged students in schooling and higher education. Australian Educational Researcher. 38 (1),Pages 109-124.

Nahtigal, L. , Haček, M. (2013). Politicization of senior civil servants in

Slovenia. Transylvanian Review of Administrative Sciences.39. P.108-127.

Klaas J., Vagizova V. Formation of sustainable development strategy of credit organizations based on Balanced Scorecard // Investment Management and Financial Innovations. - 2014. - № 1. c. 87-96. 